\title{
Activity-type dependent conductance relationships in a model neuron database
}

\author{
Amber E Hudson ${ }^{* 1}$ and Astrid A Prinz ${ }^{2}$
}

\author{
Address: ${ }^{1}$ Bioengineering, Georgia Institute of Technology, Atlanta, GA 30332, USA and ${ }^{2}$ Biology, Emory University, Atlanta, GA 30322, USA \\ Email: Amber E Hudson* - aehudson@gatech.edu \\ * Corresponding author
}

from Eighteenth Annual Computational Neuroscience Meeting: CNS*2009

Berlin, Germany. 18-23 July 2009

Published: 13 July 2009

BMC Neuroscience 2009, I0(Suppl I):P4 I doi:I0.I I86/I47|-2202-I0-SI-P4 I

This abstract is available from: http://www.biomedcentral.com/I47I-2202/I0/SI/P4 I

(c) 2009 Hudson and Prinz; licensee BioMed Central Ltd.

The stomatogastric ganglion (STG) of decapod crustaceans houses the neural circuit responsible for controlling the pyloric muscles. This neural network must produce robust rhythmic activity for successful digestion. This is a difficult task because each component cell of this system, identified by its predictable electrical activity, has a set of ion channel maximal conductances underlying its activity that varies from animal to animal. Recent experimental evidence suggests that coordinated expression and regulation of ion channels may play a role in constraining cellular electrical properties in the STG.

Here we use an existing database of generic STG conductance-based model neurons [1] to demonstrate how conductance correlations shape neural activity. These model neurons span a wide range of activity types, so the database was first partitioned based on intrinsic activity to approximate distinctions between biological cell types. Within each activity sub-division, the conductance space for that group was examined on a regular grid and individual conductance pairs were tested for linear dependence. Identified correlations became more likely as the activity segmentation criteria became more discerning (each tier in Figure 1 shows further segmentation). Broad categories of activity type, such as all periodic bursting models, did not show correlations whereas groups with narrow definitions each had several correlations (e.g. spiking models with a frequency of $10-25 \mathrm{~Hz}$ ). No conductance pairs showed a positive correlation in one activity type and a negative correlation in another. Eleven conductance pairs exhibited only positive correlations and five conductance pairs exhibited only negative correlations, whereas the remaining twelve possible conductance pairs did not demonstrate any dependence. There was a strong presence of calcium conductance correlations shown in this database. In contrast, only the hyperpolarization-activated conductance, $g_{\mathrm{H}}$, did not demonstrate linear dependence in any combination.

We conclude that regulating conductance ratios can support the maintenance of cellular activity type. Furthermore, our results show that negative correlations or correlations involving calcium conductances are plausible, and if implemented by a cell, would assist maintenance of a wide range of electrical activity types.

\section{Acknowledgements}

We would like to thank Dr. John Carew for advice on statistical analysis. This work is supported by I ROI NS0549II-0IAI from NINDS (A.A.P.) and a NSF IGERT award (A.E.H).

\section{References}

I. Prinz AA, Billimoria CP, Marder E: Alternative to hand-tuning conductance-based models: construction and analysis of databases of model neurons. J Neurophysiol 2003, 90:3998-40I5. 


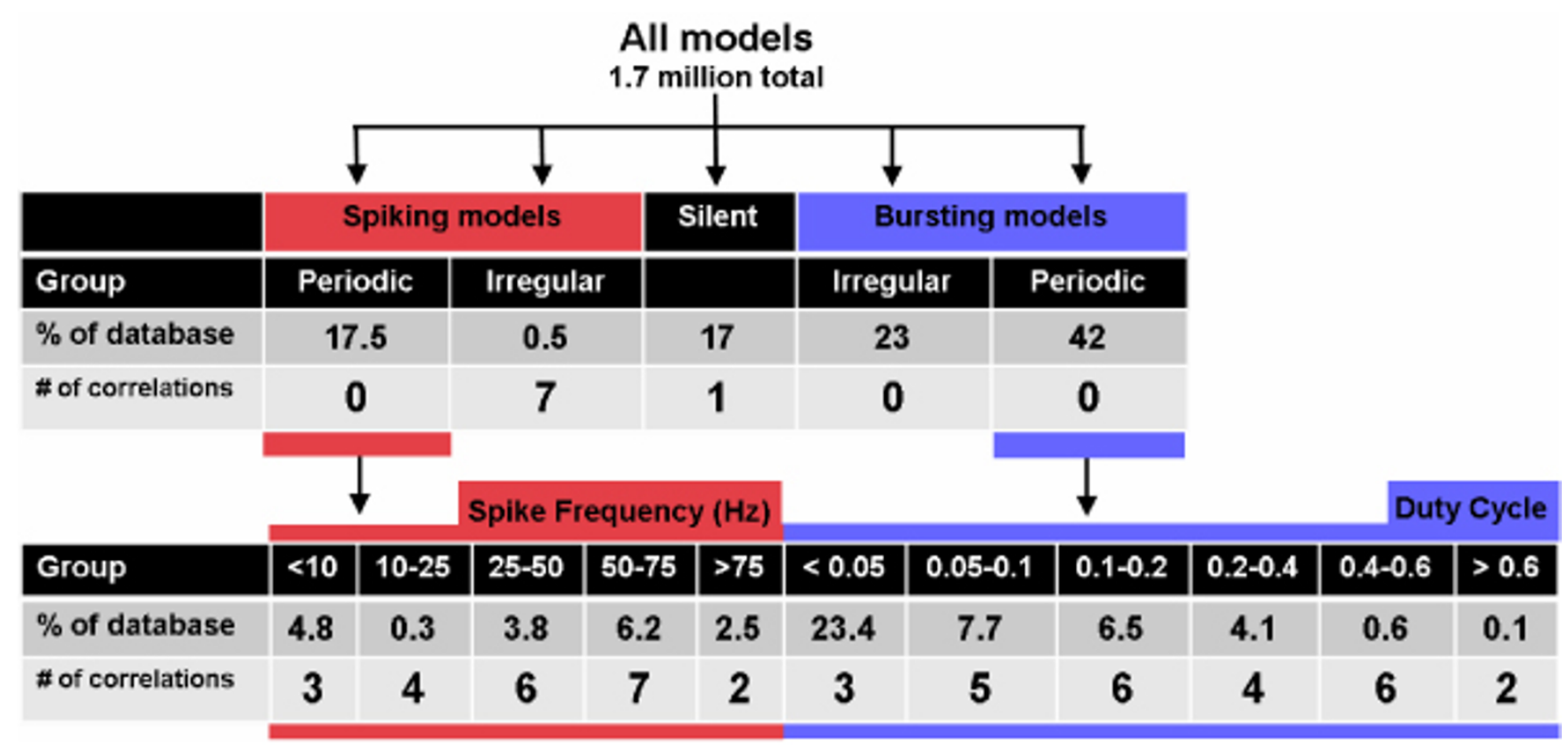

Figure I

Refined categories of activity type show a greater number of correlations.

Publish with Biomed Central and every scientist can read your work free of charge

"BioMed Central will be the most significant development for disseminating the results of biomedical research in our lifetime. "

Sir Paul Nurse, Cancer Research UK

Your research papers will be:

- available free of charge to the entire biomedical community

- peer reviewed and published immediately upon acceptance

- cited in PubMed and archived on PubMed Central

- yours - you keep the copyright 